\title{
The sensing of mitochondrial DAMPs by non-immune cells
}

\author{
Aida Rodríguez-Nuevo $0^{1,2,3}$ and Antonio Zorzano ${ }^{1,2,3, *}$ \\ ${ }^{1}$ Institute for Research in Biomedicine (IRB Barcelona). The Barcelona Institute of Science and Technology, Barcelona, Spain. \\ 2 Departament de Bioquímica i Biomedicina Molecular, Facultat de Biologia, 08028 Barcelona, Spain. \\ ${ }^{3}$ CIBER de Diabetes y Enfermedades Metabólicas Asociadas (CIBERDEM), Instituto de Salud Carlos III. \\ * Corresponding Author: \\ Antonio Zorzano, Institute for Research in Biomedicine, C/ Baldiri Reixac 10, 08028 Barcelona. Tel:+34-934037197; Fax:+34- \\ 934034717; E-mail: antonio.zorzano@irbbarcelona.org
}

\begin{abstract}
Mitochondria are the source of damage-associated molecular patterns (DAMPs), which are molecules that play a key modulatory role in immune cells. These molecules include proteins and peptides, such as $\mathrm{N}$-formyl peptides and TFAM, as well as lipids, and metabolites such as cardiolipin, succinate and ATP, and also mitochondrial DNA (mtDNA). Recent data indicate that somatic cells sense mitochondrial DAMPs and trigger protective mechanisms in response to these signals. In this review we focus on the well-described effects of mitochondrial DAMPs on immune cells and also how these molecules induce immunogenic responses in non-immune cells. Special attention will be paid to the response to mtDNA.
\end{abstract}

doi: $10.15698 /$ cst2019.06.190

Received originally: 01.10 .2018

in revised form: 03.05.2019,

Accepted 10.05.2019,

Published 23.05.2019.

Keywords: mitochondria, $D A M P$, immunity, mitochondrial DNA, TLR9, cGAS.

\begin{abstract}
Abbreviatons:
cGAS - cyclic GMP-AMP synthase, CL cardiolipin, DAMP - damage-associated molecular pattern, $\mathbf{E R}$ - endoplasmic reticulum, $\boldsymbol{F P R}$ - formyl peptide receptor, IFN - interferon, IMM - inner mitochondrial membrane, MTD - mitochondria-derived DAMP, mtDNA - mitochondrial DNA, NFP $N$-formyl peptide, OMM - outer mitochondrial membrane, PAMP pathogen-associated molecular pattern, PRR - Pattern Recognition Receptor, ROS reactive oxygen species, STING - stimulator of interferon genes, $\mathbf{T L R}-$ Toll-like receptor.
\end{abstract}

\section{MITOCHONDRIA ARE IMMUNOGENIC ORGANELLES}

The efficiency of the innate immune system is determined by the capacity of distinct cell types to discriminate self from non-self structures. The dysregulation of this ability results in either immunodeficiency pathologies or autoinflammatory and autoimmune diseases. The immune system is primed to recognize pathogen-associated molecular patterns (PAMPs), derived from infection, through a variety of receptors. However, misplaced self-molecules can also trigger similar types of responses. Such molecules are called damage-associated molecular patterns (DAMPs). Mitochondria produce DAMPs and in fact, are relevant contributors to the cellular generation of these damage signals. In this regard, both the origin and features of these molecules account for the immunogenic capacity of the mitochondrion.

Mitochondria arose around two thousand million years ago, which makes them one of the most ancient endo- membrane systems in eukaryotic cells. In 1967, Lynn Margulis rescued the long forgotten endosymbiont theory of organelle origin [1]. This proposes that eukaryotic cells derived from the engulfment of an $\alpha$-proteobacterium by the eukaryotic progenitor. The resemblance of modern mitochondria to their bacterial ancestor supports this theory. Among other features, mitochondria are comprised of two functionally different and separate membranes that surround a matrix compartment that contains the unmethylated mitochondrial circular genome, which is organized as nucleoids throughout the matrix [2]. The bacteriallike characteristics of mitochondria also reinforce the notion of them being hubs of immunity. The proteins found in mitochondria are structurally similar to those in bacteria and enable their recognition by the same receptors of the immune system [3].

Mitochondria are pivotal organelles for many cellular functions and are the primary energy-generating system in 
most eukaryotic cells. The architecture of mitochondria is essential for their proper function and also for the confinement of mitochondria-derived immunogenic molecules. At the ultrastructural level, mitochondria are comprised by two membranes, namely the outer mitochondrial membrane (OMM) and the inner mitochondrial membrane (IMM). The OMM is structurally simple and highly permeable to small molecules and ions, while at the same time it protects the cell from noxious mitochondrial products, including reactive oxygen species (ROS), immunogenic mtDNA [4] and death signals. The IMM is morphologically more complex, and it creates an impermeable barrier between the matrix and the intermembrane space. This restrictive permeability and proper cristae morphology are the two major physical features that enable mitochondria to perform oxidative phosphorylation [5]. Additionally, these organelles participate in intermediary metabolism, the regulation of programmed cell death, calcium homeostasis, and the generation and control of $\operatorname{ROS}[2,6,7]$. Mitochondrial functionality is synonymous with cellular homeostasis. In this regard, diverse molecules extruded from mitochondria alert neighboring cells, the immune system, and the producing cell itself about mitochondrial dysfunction. This signal triggers various mechanisms aimed to revert the defect and recover homeostasis, or, under chronic or more severe conditions, to induce a systemic response.

\section{MITOCHONDRIA GENERATE DIFFERENT TYPE OF IM- MUNOGENIC MOLECULES OR DAMPS}

Mitochondria-derived DAMPs (hereafter MTDs) include not only proteins but also DNA, lipids and metabolites, and they show immunogenic capacity when misplaced or imbalanced. In this review we focus on the well-described effects of MTDs on immune cells and also how these molecules induce immunogenic responses in non-immune cells.

MTDs are recognized by Pattern Recognition Receptors (PRRs). Usually, the receptors that recognize specific mitochondrial molecules are those that engage to the pathogenic homologs of these molecules. Therefore, the response triggered by MTDs resembles pathogenic effects. Hence, MTDs in sterile conditions have been studied with the aim to unravel autoimmunity and autoinflammatory diseases.

Mitochondria produce several DAMPs, such as ATP, succinate, cardiolipin, $\mathrm{N}$-formyl peptides, mtDNA and mitochondrial transcription factor A (TFAM), which serve as danger flags for immunological signaling (Figure 1) [4, 811].

In addition to being the source of DAMPs, mitochondria are also linked to immunity through their role as innate immune platforms that harbor the mitochondrial antiviralsignaling protein (MAVS) as a viral RNA sensor and the Nod-like receptor 3 (NLRP3) inflammasome as a multiple immunogenic receptor [12-16].

\section{Adenosine triphosphate}

ATP is the energetic currency in all living organisms. It is synthesized mainly in mitochondria by ATP synthase cou- pled to the electron transport chain in the IMM. It is transported to the cytosol by the ATP-ADP translocase and used by many energy-demanding reactions in the cell. The conversion from adenosine triphosphate to adenosine diphosphate through the donation of a phosphate group enables biochemical reactions.

In addition to the crucial role of intracellular ATP as an energy source for the maintenance of cellular homeostasis, it is also a key player in extracellular signaling. ATP is released from cells by cell damage, exocytosis as well as by non-vesicular mechanisms, which include ATP release channels [17]. It has been demonstrated that extracellular ATP is sensed by P2XR and P2YR receptors in the plasma membrane $[18,19]$. ATP is secreted from various types of cells under stress conditions. For instance, bacterial, hypotonic and mechanical insults on epithelial cells result in increased secretion of ATP [20-22]. High levels of extracellular ATP are sensed by leukocytes and promote relaxation, vasodilatation, neurotransmission, platelet aggregation, ion transport regulation, cell growth, and immune response-all processes triggered in response to tissue damage [23-25]. In particular, neutrophils activate chemotaxis, release IL-8 and elastase, increase adhesion capacity to endothelial cells, cause degranulation, and produce ROS and ATP to further enhance the innate immune response [26]. In monocytes and macrophages, extracellular ATP promotes the production of the pro-inflammatory cytokines IL-1 $\beta$ and IL-18. ATP binds to P2X7 receptor and induces $\mathrm{K}^{+}$efflux through the $\mathrm{P} 2 \mathrm{X} 7$ channel. This results in caspase-1 cleavage in the NLRP3 inflammasome, which in turn promotes cytokine maturation and secretion [27, 28]. Both in monocytes and T lymphocytes, ATP induces shedding of L-selectin by P2X7R activation, thereby leading to transmigration through the endothelium. These observations thus indicate the involvement of ATP in both innate and adaptive immunity [29].

\section{Succinate}

Succinate is an intermediate of the tricarboxylic acid (TCA) cycle that is generated from succinyl-CoA via succinyl-CoA ligase. However, succinate has been shown to be secreted to the extracellular media in vitro, and this is stimulated by antimycin A treatment, which inhibits electron transfer between cytochrome $b$ and $c 1$ [30]. Indeed, extracellular succinate acts as a signaling molecule and is recognized by immune cells through its G-protein-couple receptor, namely succinate receptor 1 (SUCNR1, also named GPR91) [31]. The activation of the receptor stabilizes hypoxia-inducible factor-1 alpha (HIF-1 $\alpha$ ), which favors the pro-inflammatory differentiation of T lymphocytes [32]. Succinate is also described to have synergic effects with Toll-like receptor (TLR) ligands in dendritic cells for the production of cytokines.

\section{Cardiolipin}

Cardiolipin (CL) is a phospholipid that accounts for $20 \%$ of total lipid content in the IMM [33-35]. CL is composed of two phosphatidylglyceride backbones and a glycerol head 


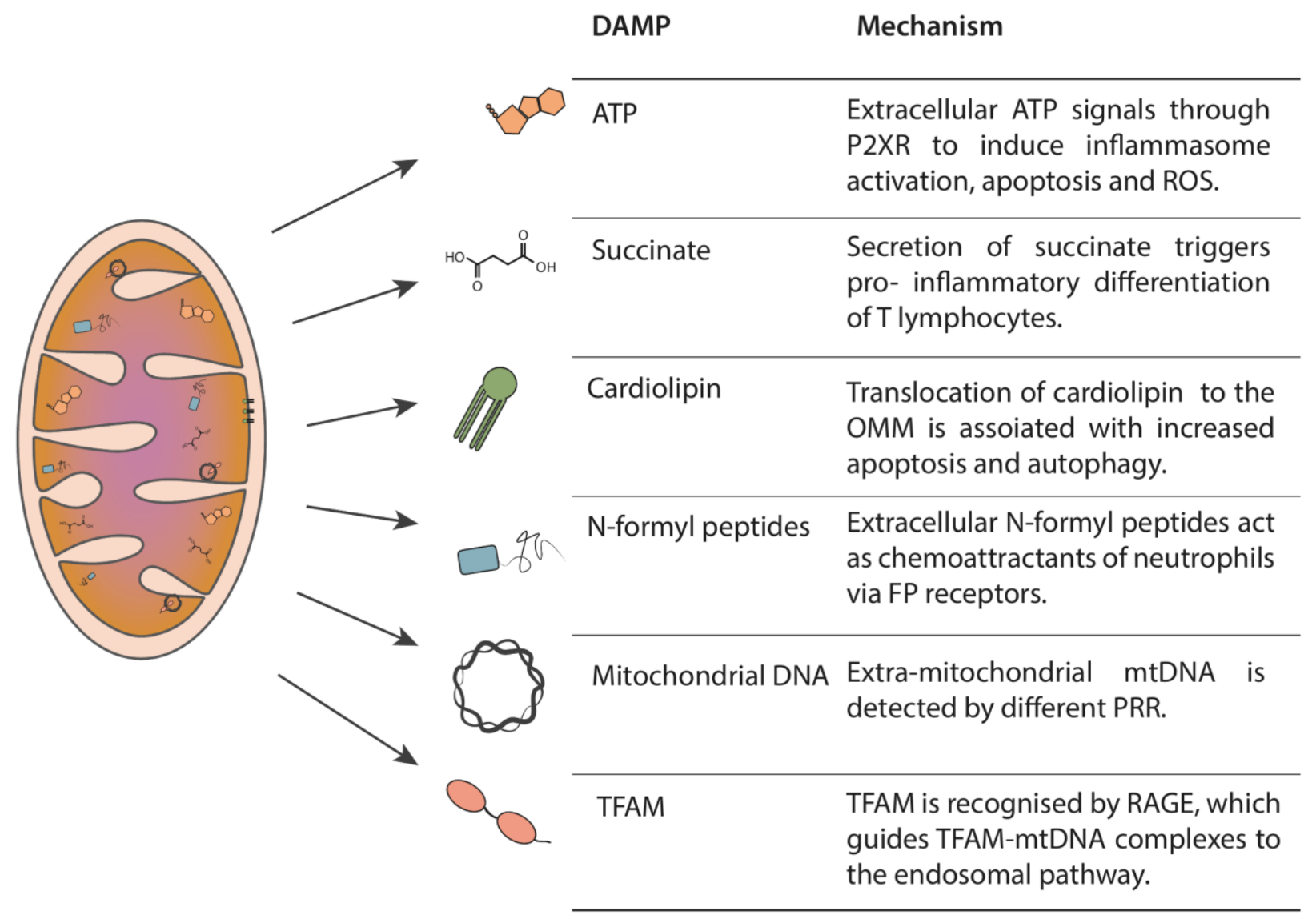

FIGURE 1: Mitochondria-derived DAMPs. Mitochondria generate immunogenic molecules, named damage associated molecular patters (DAMPS). The scheme represents the localization of the different DAMPs in their non-immunogenic state, as well as a brief description of their immunogenic capacity when misplaced.

group. Four fatty acids chains, with different lengths and degrees of saturation, are bound to CL [36]. This phospholipid is pivotal in many mitochondrial processes, including protein import, dynamics, respiratory chain functionality, and metabolism [37, 38]. Cellular necrosis exposes $C L$ to the extracellular media, which can be sensed by $T$ cells through CD1d [39]. Also, CL can bind directly to NLRP3 and activate inflammasome-mediated immune response [40]. $\mathrm{CL}$ is increased in tracheal aspirates of human pneumonia patients, as well as in lung injury models [41]. However, like other MTDs, CL is found in both bacterial and mitochondrial membranes. Therefore, to date, it has been difficult to verify the origin of pathology-associated high levels of this phospholipid in the extracellular media.

\section{$\mathrm{N}$-formyl peptides}

Bacteria use the addition of a formyl group, a carbonyl bonded to hydrogen, to methionine to initiate protein synthesis. Bacterial $\mathrm{N}$-formyl peptides (NFPs) serve as chemoattractants to activate host phagocytes [42]. Polymorphonuclear and mononuclear phagocytes show high expression of formyl peptide receptors (FPRs), members of the seven families of transmembrane $G$ protein-couple recep- tors [43]. Recognition of NFPs by FPR in the plasma membrane of the phagocyte initiates various defense responses of the immune cell, such as morphological polarization, locomotion, phagocytosis, ROS generation, and protease secretion [42]. NFPs were first described to present chemoattractant capacity for neutrophils and platelets [44, 45] Mice unable to detect NFPs, by genetic knockout of formyl peptide receptor 1 , show higher susceptibility to infection by Listeria monocytogenes [46]. In humans, localized juvenile periodontitis patients carry dysfunctional variant alleles of the FPR gene and present reduced neutrophil chemotaxis capacity to NFPs $[47,48]$. Interestingly, NFPs are extruded not only by pathogens like Escherichia coli but also by the mitochondria of damaged or dying cells. Mitochondrial formylation of methionine is needed for translation initiation of mRNA transcribed from mtDNA, a mechanism reminiscent of bacteria [49]. Thus, mitochondria produce NFP due to the translation of mtDNA-encoded proteins within the mitochondrial matrix. Mitochondrial extracts of NFPs induce the chemotaxis of polymorphonuclear cells, whereas the non-formylated peptides are innocuous. Moreover, NFPs are secreted only by necrotic cells, thus excluding apoptotic cells [45]. These observations 
suggest that NFPs have dual roles in tissue homeostasis. On the one hand, they promote the clearance of bacteria and infected cells. On the other hand, they enable the identification of damage cells undergoing necrosis, a process that will lead to extrusion of mitochondrial content. NFPs therefore allow the rapid clearance of these damaged cells by phagocytes.

\section{Mitochondrial DNA}

The mitochondrial genome is a double-stranded circular DNA molecule of around 16 kilobases, present in hundreds to thousands of copies per cell. It is packed with nucleoids, which are slightly elongated, irregularly shaped structures of approximately $80-100 \mathrm{~nm}$. Nucleoids associate with the IMM and distribute throughout mitochondria [50]. They contain relatively high levels of TFAM (1 subunit every 16$17 \mathrm{bp}$ of mtDNA), which is essential for mtDNA maintenance because it is responsible for mtDNA packaging [5156]. There is some debate regarding the number of mtDNA copies per nucleoid. While some authors have described several copies of mtDNA per nucleoid [57], others have reported only one copy $[56,58]$. The organization of mtDNA into nucleoids is essential for the correct distribution and segregation of mtDNA. The mitochondrial genome encodes for 22 tRNA, 2 rRNA and 13 essential subunits of the mitochondrial oxidative phosphorylation system: complex I (ND1-ND6), complex III (Cyt b), complex IV (COX ICOX III), and complex $V(A 8$ and A6). It also contains a few non-coding sequences, the largest being the displacement loop (D-loop). This region of the mtDNA is also denominated the control region, because it contains the promoter for the transcription of both light and heavy strands (LSP and HSP) and the origin of replication for the heavy strand [59, 60].

Owing to the $\alpha$-proteobacterial origin of mitochondria, mtDNA has unique features that are important for its role in innate immune responses and inflammation. Misplaced mtDNA has been widely shown to induce a proinflammatory state $[4,61-65]$. Methylation of the $\mathrm{CpG}$ regions in mtDNA differs to that of the nuclear DNA and confers mtDNA with immunogenic potential due to its resemblance to DNA of pathogens, specially bacteria. Some authors have described the absence of methylation in mtDNA, while others report that the nuclear DNA methyltransferase (DNMT1) is found in mitochondria, thereby suggesting some degree of methylation in mammalian cells $[66,67]$. In addition to hypomethylation, mtDNA can undergo oxidative damage, which is immunogenic and can be recognized by PRRs, independently of the degree of methylation $[68,69]$. Extracellular mtDNA binds TLR9, which has also been described to recognize unmethylated or undermethylated CpG DNA. In macrophages, mtDNA engagement with TLR9 induces the production of proinflammatory cytokines, chemotaxis and phagocytic activation through a MyD88-dependent signaling cascade. TLR9 has been associated with the development of polymicrobial acute kidney injury through the recognition of mtDNA release [70].
High levels of circulating mtDNA have been linked to liver dysfunction and increased neutrophil-mediated inflammatory responses [71]. The injection of mtDNA induces lung injury and arthritis with infiltration of mononuclear cells in mice [72]. These data support the notion that mtDNA participates in the development of inflammatory responses in vivo $[4,73]$. mtDNA also induces inflammation in microglial and neuronal cells or in mouse brains [74, 75]. Furthermore, it has been reported that mtDNA stress elicited by TFAM deficiency triggers cytosolic antiviral signaling, promoted by cytosolic mtDNA leakage [64]. Thus, the degree of packaging, the stability, the localization and the presence of oxidative damage modifications or mutations are implicated in mtDNA-innate immune signaling [12].

\section{TFAM}

Mitochondrial transcription factor A (TFAM) is member of the HMG box family of proteins. TFAM interacts with mitochondrial DNA and regulates both its transcription and replication, thus modulating mtDNA-encoded protein expression and mtDNA copy number $[76,77]$. TFAM correct expression is crucial for mitochondrial function and thus cellular homeostasis [55]. The presence of extracellular TFAM is described to induce an inflammatory response, similarly to the action of another DAMP of the same family of proteins, namely HMGB1. TFAM also enhances the immunogenicity of mtDNA [78]. While bound to mtDNA, it can interact with the plasma membrane receptor RAGE and induces the internalization of mtDNA, thereby promoting its recognition by TLR9 [79]. Also, TFAM enhances cytokine secretion in combination with NFPs [80]. Treatment with TFAM increases the levels of 116 and TNF in the serum of rats and in the media from RAW264.7 macrophage cultures [81].

\section{NON-IMMUNE CELLS ALSO RESPOND TO} MITOCHONDRIAL DAMPS

Mitochondrial DAMPs were initially reported in cells of the immune system [82]. However, we now know that somatic cells also respond to mitochondrial DAMPs to either trigger protective mechanisms or pathways to exacerbate the signal. In this regard, the release of mitochondrial DAMPs in ischemia/reperfusion during liver transplantation, together with pro-inflammatory cytokines, causes hepatic inflammation and cell death [83]. In contrast, some mitochondrial DAMPs may have a protective role. The activation of the P2X7 receptor, an ATP-gated trimeric membrane cation channel, induces plasmalemmal blebbing [84], which prevents cellular damage triggered by bacterial pore-forming toxins. On the basis of these data, it has been proposed that ATP modulates inflammation and prevents cell death upon activation of the $\mathrm{P} 2 \mathrm{X} 7$ receptor.

Necrosis is not strictly necessary for the release of mitochondrial DAMPs. Duregatti and colleagues reported that neurons treated with presynaptic toxins release hydrogen peroxide, as well as mtDNA and cytochrome c, secondary to mitochondrial dysfunction. These DAMPs activate Schwann cells to initiate neural degeneration. The release 
of mtDNA and cytochrome c results from the opening of the mitochondrial transition pore, and the maintenance of mitochondrial permeability was shown to be key to restraining mitochondrial DAMP release [85].

Cardiolipin is asymmetrically enriched in the IMM. Under stimuli determining cell or mitochondrial dysfunction such as membrane depolarization or tBid binding, $\mathrm{CL}$ is translocated to the OMM, a process facilitated by the phospholipid scramblase 3 (PLS3) [86]. The presence of $\mathrm{CL}$ in the OMM induces mitophagy [87], and apoptosis by reducing OMM permeability and thus enabling cytochrome c release. Regarding the immunogenic capacity of $\mathrm{CL}$, it acts as a signaling platform in the recruitment of inflammasome particles and to induce the activation of these molecules [86, 88].

Mitochondrial DAMPs can play modulatory roles, for example, by increasing endothelial cell permeability, thus allowing the transmission of the immunogenic response to distal organs [89]. These studies indicate that mitochondrial DAMPs are important in the different levels of the immunogenic response in non-immune cells.

The regulatory role of succinate or $\mathrm{N}$-formyl peptides in non-immune cells remains unclear. However, given that the expression of the succinate receptor, SUCNR1, is high in liver and kidney [90], it is likely that it mediates mitochondrial stress in these tissues. Similarly, N-formyl peptide receptors FPR1 and FPR2 show a relative broad expression so they may also play a modulatory role in various tissues [91].

\section{MECHANISMS OF RESPONSE TO MITOCHONDRIAL DNA}

Since nucleic acids are central for the replication and propagation of most pathogens, it is not surprising that their detection is covered by various kinds of PRRs localized in diverse cellular compartments. In particular, mtDNA is recognized by four innate immune receptors: cytosolic cyclic GMP-AMP synthase (cGAS), endosomal TLR9, and the two inflammasomes: Absent In Melanoma 2 (AIM2), and NOD, LRR and Pyrin domain-containing protein 3 (NLRP3) [92, 93]. Here we focus mainly on cGAS and TLR9 as mtDNA sensors since the mechanism through which mtDNA activates inflammasomes is poorly characterized.

\section{Mitochondrial DNA and cGAS signaling}

cGAS is the most recently described DNA sensor [94, 95]. Cytosolic double stranded (ds)DNA activates CGAS to form a dimeric cGAS-DNA complex that synthesizes cyclic GMPAMP or CGAMP from ATP and GTP. This cGAMP functions as a second messenger because it is a high-affinity ligand for the endoplasmic reticulum (ER) membrane adaptor protein stimulator of interferon genes (STING) [96]. cGAMP induces conformational changes in STING, which results in the subsequent activation of the transcription factors NF$\kappa B$ and IRF3 through the kinases IKK and TBK1, respectively (Figure 2) [97-101]. Interestingly, cGAS induces autophagy independently of STING as a protective mechanism against ischemia-reperfusion injury in liver [102].
Under conditions in which DNA is bound to HMGB1 or TFAM and forms a protein-DNA ladder, cGAS signaling is promoted [103]. Specifically, mtDNA has been reported to trigger a type I interferon (IFN) response and expression of IFN-stimulated genes (ISG) in a Tfam heterozygous context [64]. West and colleagues observed mtDNA stress, characterized by reduced nucleoid number and increased nucleoid size. In these conditions, mtDNA was found in the cytosolic fraction in the context of mitochondrial hyperfusion. Interestingly depletion of mitochondrial fusion protein Mfn1 normalizes ISG expression. In obesity-induced insulin resistance, the release of mtDNA to the cytosol has been described as a major driver of the chronic inflammation associated with the disease, through the activation of the cGAS-STING pathway [104]. This pathway is also activated upon release of mtDNA in apoptotic conditions, although the apoptosis pathway silences the immunogenic response. McArthur and colleagues used apoptosis as a model situation of mtDNA release to the cytosol and found that the BAK/BAX macropore allows the IMM to herniate, creating a protrusion in the mitochondrial surfaces of naked IMM. The loss of membrane integrity then allowed exposure of mtDNA to the cytosol [105].

\section{Mitochondrial DNA as a TLR9 agonist}

TLR9 was the first protein of the TLR family to be described as a nucleic acid sensor (Figure 2). It is expressed mainly in immune system cells, including dendritic cells and macrophages. However, it is also found in other non-immune cells such as muscle and epithelial cells, among others [106]. It binds specifically to unmethylated CpG DNA, like the mtDNA, in the endolysosomal compartment $[12,107-$ 109]. TLR9 signals through the myeloid differentiation primary response protein 88 (MyD88), which activates a number of kinases and transcriptional factors, namely $\mathrm{mi}-$ togen-activated protein kinases (MAPK), nuclear factor- $\kappa B$ (NF-KB) and IRF7 to enhance pro-inflammatory and type I interferon responses, respectively. Nucleic acid-sensing TLRs are not detectable at the cell surface but instead reside within internal compartments. In particular, full-length TLR9 localizes in the ER under unstimulated conditions [110]. More recent studies have identified that, upon stimulation, full-length TLR9 traffics through the Golgi apparatus to the endolysosomal compartment, guided by the accessory protein UNC93B1, and it is then cleaved to become DNA sensing-competent [111-115]. The recruitment of TLR9 to the endolysosomal compartment is key for its function since proteolytic activation of TLR9 occurs in endosomes, and in addition, MyD88 localizes in this compartment.

There is some evidence suggesting that the specific endolysosomal compartment in which the interaction between DNA and TLR9 takes place determines the type of immune response generated [116, 117]. Thus, it has been proposed that TLR9 signaling from late endosomes leads to the activation of NF-KB, whereas TLR9 signaling from a distinct population of endosomes brings about the recruitment of IRF and induction of type I IFN (IFN-a, IFN-b). 


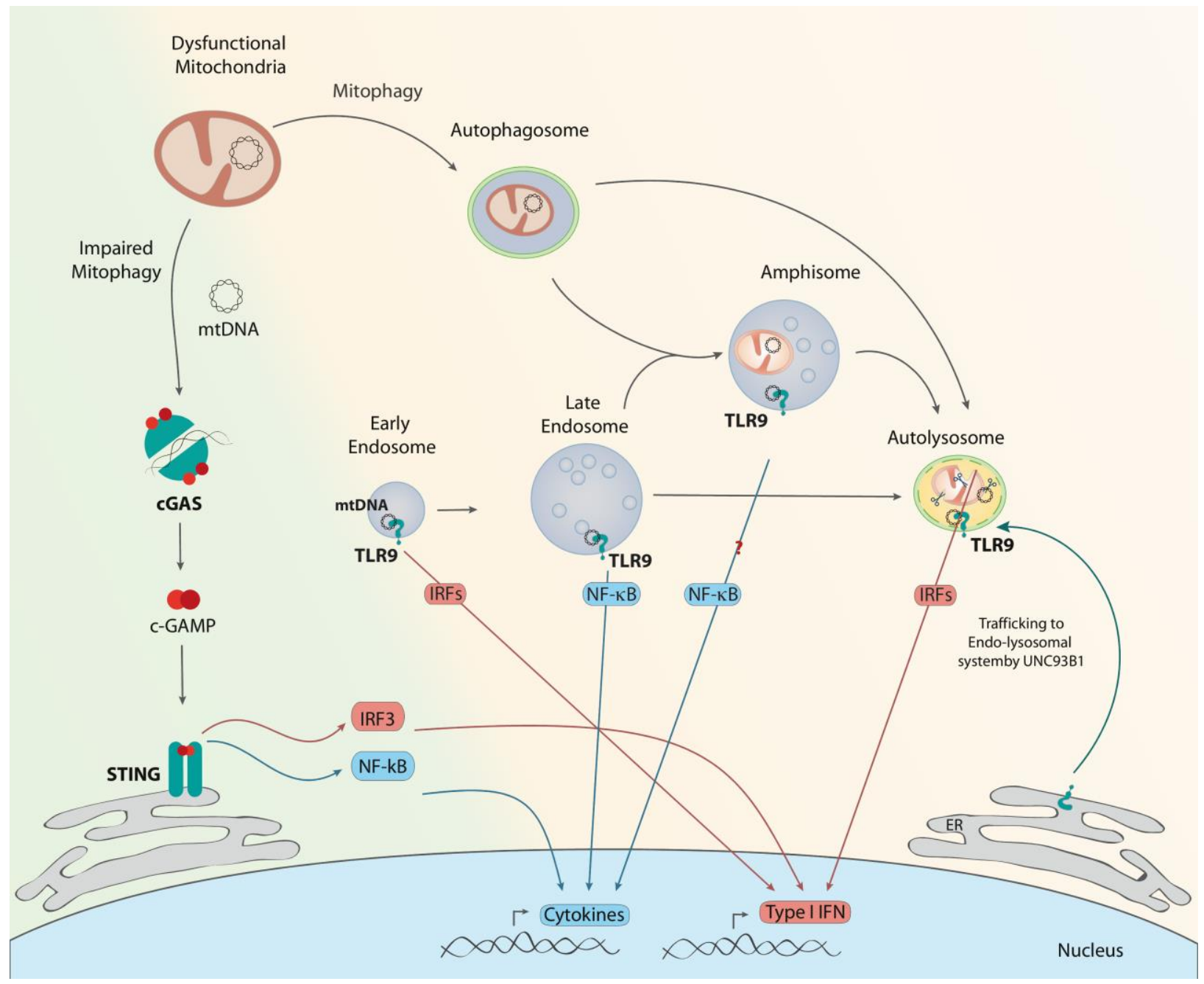

FIGURE 2: cGAS and TLR9 activation by mtDNA. Under conditions of impaired mitophagy initiation (green background), thus accumulation of dysfunctional mitochondria, there is mtDNA leakage to the cytosol. cGAS homodimers recognize double stranded DNA as mtDNA and produce c-GAMP, which interacts with STING, triggering IRF3 or NF-KB, and in turn the expression of type I IFNs or cytokines, respectively. Under conditions in which mitophagosomal formation occurs normally but resolution is defective (orange background), mtDNA instability can lead to its recognition by TLR9 in different endosomal compartments. TLR9 is recruited from the ER to the endo-lysosomal system, guided by UNC93B1. Engagement of TLR9 in early endosomes or lysosomes results in type I IFN expression through various IRFs. Interaction of mtDNA with TLR9 in late endosomes results in NF-KB activation. Given the resemblance of amphisomes to late endosomes, TLR9 engagement in amphisomes could result in cytokine production.

This alternative compartment is hypothesized to be either early endosomes or lysosomes [118, 119]. Interestingly, TLR9 modulates energy metabolism in cardiomyocytes [120], reduces ATP, and enhances AMPK activity [121]. In all, distinct cellular responses can be elicited in different cell types through the activation of the TLR9 receptor system.

Regarding mtDNA, unmethylated CpG motifs of mtDNA trigger TLR9 signaling. Several studies have reported the relevance of circulating or extracellular mtDNA in TLR9dependent inflammation in diseases such as rheumatoid arthritis [122], atherosclerosis [10, 123], acute liver injury [71], and Streptococcus pneumoniae infections [124], among others [10, 62, 125-129]. Rats subjected to vascular injury showed increased extracellular mtDNA, which led to lung tissue damage through a TLR9-dependent pathway [130]. In pregnancy, high levels of cell death are associated with preeclampsia through a mechanism involving mtDNA and TLR9 [131] Also, high mtDNA levels in non-alcoholic steatohepatitis patients are reported to activate TLR9 and exacerbate the inflammatory profile [129]. Moreover, high mobility group protein B1 (HMGB1), a nuclear DNA-binding protein released from necrotic cells, was found to be an essential component of DNA-containing immune complexes that stimulate cytokine production through a TLR9MyD88 pathway involving the multivalent receptor RAGE [132]. Similarly, extracellular TFAM-bound mtDNA can induce a further stronger NF- $\kappa B$ activation since plasma membrane receptor RAGE interacts with TFAM and delivers mtDNA to TLR9 [133]. 
Mitochondrial DNA engages with TLR9 in the lysosomes of DNase II-deficient hearts, thereby suggesting that undegraded mtDNA escaping from autophagy induces TLR9 and causes inflammation in cardiomyocytes [61]. In parallel, De Leo et al. reported a non-inflammatory role of the TLR9DNA interaction in the lysosome cargo response, which is required to sustain the autophagic flux [134]. In skeletal muscle, ablation of the mitochondrial fusion protein Opa1 leads to a severe mitochondrial inflammatory myopathy, which is caused by TLR9 activation through a mechanism that requires mtDNA [135]. This inflammatory process is a primary cell-autonomous response of muscle cells to Opa1 deficiency and it leads to NF-KB activation [135]. Another less characterized response of TLR9 is the interaction with mIDNA and HMGB1 in the cytosol during hypoxia, which is involved in tumor growth [136]. In all, various mechanisms have been implicated in TLR9-associated pathologies. This is not surprising given the multiple factors involved in infection or injury [137-139].

\section{Inflammasome}

Mitochondrial DNA can also be recognized by two members of a superfamily of immunogenic receptors, namely the inflammasomes AIM2 and NLRP3. These are mainly cytosolic multiprotein oligomeric complexes that activate caspase- 1 , which in turn proteolytically cleaves IL-1 $\beta$ and IL-18, thus generating mature active forms of the secreted cytokines [28]. The inflammasome is triggered not only by pathogen-associated molecular patterns (PAMPs) as flags of pathogen infection but also by DAMPs, which flag cellular malfunction or stress. The activation of the inflammasome involves two sequential signals. The priming signal leads to NF-KB activation, which includes the expression of inflammasome components and inactive forms of the cytokines. This signal prepares the cell for a possible activation of the pathway in response to, for instance, pathological infection. Typically, this first signal is the engagement of a membrane PRR, for example TLR4, but it is also triggered by intracellular receptors like intraluminal TLRs, including TLR7 and TLR9. Experimentally, lipopolysaccharide (LPS) is widely used to prime cells for inflammasome activation.

The second signal is the trigger itself, which interacts with the recognition part of the complex and leads to the oligomerization and activation of the inflammasome particle. In addition to the recognition protein, which is specific for each type of inflammasome, a scaffold protein, the adaptor protein known as ASC, is common to all of them. This protein serves as a bridge from the upstream inflammasome sensor molecule to caspase 1 . Inflammasome assembly and oligomerization results in the cleavage of caspase 1 , which in turn causes rapid and efficient activation and secretion of large amounts of IL- $1 \beta$, which were already expressed in response to the priming signal. Inflammasomes fall into several categories. In this regard, Broz and Dixit classified them into the following the groups: 1) the nucleotide-binding oligomerization domain (NOD); the leucine-rich repeat (LRR)-containing protein (NLR) or NLR inflammasomes; 2) the absent in melanoma 2 (AIM2) and pyrin inflammasomes, which are canonical in- flammasomes; and 3) non-canonical inflammasomes [140]. NLRP3 is the most studied type of inflammasome, yet the mechanisms of activation are so diverse that there is no consensus regarding whether it has affinity for a wide range of molecules or whether there is an unknown intracellular signal that converges all the different triggers into NLRP3 activation [16, 141, 142]. Classically, the inflammasome has been addressed only in macrophages and other inflammatory cells. However, several studies have reported inflammasome activation in non-immune cells, like podocytes, hepatocytes, and cardiac and skeletal myocytes [143-149]. The involvement of mtDNA in the activation of NLRP3 was reported upon mitochondrial dysfunction, leading to mtDNA leakage to the cytosol in primed macrophages [68]. In fact, mitochondria are proposed to harbour NLRP3 and be able to regulate the activity of the inflammasome complex. On one hand, activation of mitophagy reduces inflammation by clearing mitochondrialbound NLRP3 complexes. On the other hand, mitochondrial ROS can exacerbate inflammasome immunogenic signal [14].

\section{CONCLUSIONS AND PERSPECTIVES}

Mitochondrial DAMPs have been studied mainly in the context of the function of immune cells, and we now know that they play a key role in the activity of the innate immune system, as well as in pathologies associated with immunodeficiencies and autoimmune and autoinflammatory diseases. In this regard, the mechanism by which mitochondrial dysfunction leads to the release of the different DAMPs described and the conditions under which some molecules predominate over others remain elusive. Specific studies are required to clarify this point.

There is a fragmented understanding of the cellular mechanisms that delocalize mtDNA and generate mitochondrial DAMPs. In this context, further research is needed. The relative role of the different cytosolic sensors to mitochondrial DNA should be clarified. In short, a greater knowledge of the stability and targeting of mtDNA and its sensors will allow us to predict the response of given cells to the generation of mitochondrial DAMPs triggered by specific mitochondrial damage.

Finally, future research should seek to unravel how non-immune cells respond to mitochondrial damage caused by the release of DAMPs, and mechanisms involved in these responses. Of particular relevance is understanding those conditions in which the damage to non-immune cells leads to chronic inflammatory responses. The findings of such lines of research would contribute to shedding light on diseases that are only partially understood, as is the case of inflammatory myopathies, and would also help to define pharmacological treatments for the same.

\section{ACKNOWLEDGMENTS}

A.R-N. was the recipient of a FPI fellowship from the "Ministerio de Educación y Cultura", Spain. This study was supported by research grants from the MINECO (SAF201675246R), Generalitat de Catalunya (grant 2014SGR48), 
INFLAMES (PIE-14/00045) from the Instituto de Salud Carlos III, and CIBERDEM (Instituto de Salud Carlos III). A.Z. is a recipient of an ICREA "Academia" (Generalitat de Catalunya). We gratefully acknowledge institutional funding from the MINECO through the Centres of Excellence Severo Ochoa Award, and from the CERCA Programme of the Generalitat de Catalunya.

\section{CONFLICT OF INTEREST}

Authors show no conflict of interest in connection with this manuscript.

\section{REFERENCES}

1. Sagan $L$ (1967). On the origin of mitosing cells. J Theor Biol 14(3): 225-IN6. doi: 10.1016/0022-5193(67)90079-3

2. Nunnari J, and Suomalainen A (2012). Mitochondria: In sickness and in health. Cell 148(6): 1145-1159. doi: 10.1016/j.cell.2012.02.035

3. Pallen MJ (2011). Time to recognise that mitochondria are bacteria? Trends Microbiol 19(2): 58-64. doi: 10.1016/j.tim.2010.11.001

4. Zhang $Q$, Raoof $M$, Chen $Y$, Sumi $Y$, Sursal $T$, Junger $W$, Brohi $K$, Itagaki K, and Hauser CJ (2010). Circulating mitochondrial DAMPs cause inflammatory responses to injury. Nature 464(7285): 104-7. doi: $10.1038 /$ nature 08780

5. Jayashankar V, Mueller IA, and Rafelski SM (2016). Shaping the multi-scale architecture of mitochondria. Curr Opin Cell Biol 38: 4551. doi: 10.1016/j.ceb.2016.02.006

6. Gunter TE, Buntinas L, Sparagna GC, and Gunter KK (1998). The $\mathrm{Ca} 2+$ transport mechanisms of mitochondria and $\mathrm{Ca} 2+$ uptake from physiological-type Ca2+ transients. Biochim Biophys Acta 1366(1-2) 5-15. doi: 10.1016/s0005-2728(98)00117-0

7. Hockenbery D, Nunez G, Milliman C, Schreiber RD, and Korsmeyer SJ (1990). Bcl-2 is an inner mitochondrial membrane protein that blocks programmed cell death. Nature 348(6299): 334-336. doi: $10.1038 / 348334 a 0$

8. Krysko D V, Agostinis P, Krysko O, Garg AD, Bachert C, Lambrecht $B N$, and Vandenabeele $P$ (2011). Emerging role of damage-associated molecular patterns derived from mitochondria in inflammation. Cell 32(4): 157-64. doi: 10.1016/j.it.2011.01.005

9. Nakahira K, Hisata S, and Choi AM (2015). The roles of Mitochondrial DAMPs in Diseases. Antioxid Redox Signal 23(17): 1-78. doi: 10.1089/ars.2015.6407

10. Yu EPK, and Bennett MR (2014). Mitochondrial DNA damage and atherosclerosis. Trends Endocrinol Metab 25(9): 481-7. doi: 10.1016/j.tem.2014.06.008

11. Arnoult D, Soares F, Tattoli I, and Girardin SE (2011). Mitochondria in innate immunity. EMBO Rep 12(9): 901-910. doi: 10.1038/embor.2011.157

12. West AP, Shadel GS, and Ghosh S (2011). Mitochondria in innate immune responses. Nat Rev Immunol 11(6): 389-402. doi: 10.1038/nri2975

13. Mills EL, Kelly B, and O'Neill LAJ (2017). Mitochondria are the powerhouses of immunity. Nat Immunol 18(5): 488-498. doi: $10.1038 /$ ni.3704

14. Zhou R, Yazdi AS, Menu P, and Tschopp J (2011). A role for mitochondria in NLRP3 inflammasome activation. Nature 469(7329): 2215. doi: 10.1038/nature09663

\section{COPYRIGHT}

(C) 2019 Rodríguez-Nuevo and Zorzano. This is an openaccess article released under the terms of the Creative Commons Attribution (CC BY) license, which allows the unrestricted use, distribution, and reproduction in any medium, provided the original author and source are acknowledged.

Please cite this article as: Aida Rodríguez-Nuevo and Antonio Zorzano (2019). The sensing of mitochondrial DAMPs by non-immune cells. Cell Stress 3(6): 195-207. doi: 10.15698/cst2019.06.190

15. Koshiba T, Yasukawa K, Yanagi Y, and Kawabata S (2011). Mito chondrial membrane potential is required for MAVS-mediated antiviral signaling. Sci Signal 4(158): ra7. doi: 10.1126/scisignal.2001147

16. Sutterwala FS, Haasken S, and Cassel SL (2014). Mechanism of NLRP3 inflammasome activation. Ann N Y Acad Sci 1319(1): 82-95. doi: $10.1111 /$ nyas. 12458

17. Taruno A (2018). ATP release channels. Int J Mol Sci 19(3): E808. doi: $10.3390 /$ ijms 19030808

18. Sluyter $R$, and Stokes $L$ (2011). Significance of $P 2 X 7$ receptor variants to human health and disease. Recent Pat DNA Gene Seq 5(1): 41-54. doi: 10.2174/187221511794839219

19. Fuller SJ, Stokes L, Skarratt KK, Gu BJ, and Wiley JS (2009). Genetics of the P2X7 receptor and human disease. Purinergic Signal 5(2): 257262. doi: $10.1007 /$ s11302-009-9136-4

20. Save S, and Persson K (2010). Extracellular ATP and P2Y receptor activation induce a proinflammatory host response in the human urinary tract. Infect Immun 78(8): 3609-3615. doi: 10.1128/IAI.0007410

21. Hazama A, Shimizu T, Ando-Akatsuka Y, Hayashi S, Tanaka S, Maeno $E$, and Okada $Y$ (1999). Swelling-induced, CFTR-independent ATP release from a human epithelial cell line: lack of correlation with volume-sensitive cl(-) channels. J Gen Physiol 114(4): 525-533. doi: 10.1085/jgp.114.4.525

22. Grygorczyk R, and Hanrahan JW (1997). CFTR-independent ATP release from epithelial cells triggered by mechanical stimuli. Am Physiol 272(3 Pt 1): C1058-66. doi: 10.1152/ajpcell.1997.272.3.C1058

23. Deli T, and Csernoch L (2008). Extracellular ATP and cancer: an overview with special reference to P2 purinergic receptors. Pathol Oncol Res 14(3): 219-231. doi: 10.1007/s12253-008-9071-7

24. Sprague RS, Olearczyk JJ, Spence DM, Stephenson AH, Sprung RW, and Lonigro AJ (2003). Extracellular ATP signaling in the rabbit lung: erythrocytes as determinants of vascular resistance. Am J Physiol Heart Circ Physiol 285(2): H693-700. doi: 10.1152/ajpheart.01026.2002

25. Burnstock $G$ (2006). Pathophysiology and therapeutic potential of purinergic signaling. Pharmacol Rev 58(1): 58-86. doi: 10.1124/pr.58.1.5

26. Bours MJL, Swennen ELR, Di Virgilio F, Cronstein BN, and Dagnelie PC (2006). Adenosine 5'-triphosphate and adenosine as endogenous signaling molecules in immunity and inflammation. Pharmacol Ther 112(2): 358-404. doi: 10.1016/j.pharmthera.2005.04.013

27. Rathinam VAK, and Fitzgerald KA (2016). Inflammasome Complexes: Emerging Mechanisms and Effector Functions. Cell 165(4): 792800. doi: 10.1016/j.cell.2016.03.046 
28. Lamkanfi M, and Dixit VM (2014). Mechanisms and Functions of Inflammasomes. Cell 157(5): 1013-1022. doi 10.1016/j.cell.2014.04.007

29. Jamieson GP, Snook MB, Thurlow PJ, and Wiley JS (1996). Extracellular ATP causes loss of L-selectin from human lymphocytes via occupancy of P2Z purinoceptors. J Cell Physiol 166(3): 637-642. doi: 10.1002/(SICl)1097-4652(199603)166:3<637::AID-JCP19>3.0.CO

30. Shaham O, Slate NG, Goldberger O, Xu Q, Ramanathan A, Souza AL, Clish CB, Sims KB, and Mootha VK (2010). A plasma signature of human mitochondrial disease revealed through metabolic profiling of spent media from cultured muscle cells. Proc Natl Acad Sci U S A 107(4): 1571-1575. doi: 10.1073/pnas.0906039107

31. Rubic T, Lametschwandtner G, Jost $S$, Hinteregger S, Kund J, Carballido-Perrig $\mathrm{N}$, Schwarzler $\mathrm{C}$, Junt $\mathrm{T}$, Voshol $\mathrm{H}$, Meingassner JG, Mao $X$, Werner $G$, Rot A, and Carballido JM (2008). Triggering the succinate receptor GPR91 on dendritic cells enhances immunity. Nat Immunol 9(11): 1261-1269. doi: 10.1038/ni.1657

32. Tannahill GM et al. (2013). Succinate is an inflammatory signal that induces IL-1beta through HIF-1alpha. Nature 496(7444): 238-242. doi: $10.1038 /$ nature11986

33. Schlame M, and Greenberg ML (2017). Biosynthesis, remodeling and turnover of mitochondrial cardiolipin. Biochim Biophys Acta 1862(1): 3-7. doi: 10.1016/j.bbalip.2016.08.010

34. Tatsuta T, and Langer T (2017). Intramitochondrial phospholipid trafficking. Biochim Biophys Acta 1862(1): 81-89. doi: 10.1016/j.bbalip.2016.08.006

35. Gebert N, Joshi AS, Kutik S, Becker T, McKenzie M, Guan XL, Mooga VP, Stroud DA, Kulkarni G, Wenk MR, Rehling $P$, Meisinger $C$, Ryan MT, Wiedemann N, Greenberg ML, and Pfanner N (2009). Mitochondrial cardiolipin involved in outer-membrane protein biogenesis: implications for Barth syndrome. Curr Biol 19(24): 2133-2139. doi: 10.1016/j.cub.2009.10.074

36. Maguire JJ, Tyurina YY, Mohammadyani D, Kapralov AA, Anthonymuthu TS, Qu F, Amoscato AA, Sparvero L, Tyurin VA, PlanasIglesias J, He R-R, Klein-Seetharaman J, Bayir H, and Kagan VE (2017). Known unknowns of cardiolipin signaling: The best is yet to come. Biochim Biophys Acta 1862(1): 8-24. doi: 10.1016/j.bbalip.2016.08.001

37. Claypool SM, and Koehler CM (2012). The complexity of cardiolipin in health and disease. Trends Biochem Sci 37(1): 32-41. doi: 10.1016/j.tibs.2011.09.003

38. Chicco AJ, and Sparagna GC (2007). Role of cardiolipin alterations in mitochondrial dysfunction and disease. Am J Physiol Cell Physiol 292(1): C33-44. doi: 10.1152/ajpcell.00243.2006

39. Dieude M, Striegl H, Tyznik AJ, Wang J, Behar SM, Piccirillo CA, Levine JS, Zajonc DM, and Rauch J (2011). Cardiolipin binds to CD1d and stimulates CD1d-restricted gammadelta $T$ cells in the normal murine repertoire. J Immunol 186(8): 4771-4781. doi: 10.4049/jimmunol.1000921

40. Iyer SS, He Q, Janczy JR, Elliott El, Zhong Z, Olivier AK, Sadler JJ, Knepper-Adrian V, Han R, Qiao L, Eisenbarth SC, Nauseef WM, Cassel $\mathrm{SL}$, and Sutterwala FS (2013). Mitochondrial cardiolipin is required for Nlrp3 inflammasome activation. Immunity 39(2): 311-323. doi: 10.1016/j.immuni.2013.08.001

41. Ray NB, Durairaj L, Chen BB, McVerry BJ, Ryan AJ, Donahoe M, Waltenbaugh AK, O'Donnell CP, Henderson FC, Etscheidt CA, McCoy DM, Agassandian M, Hayes-Rowan EC, Coon TA, Butler PL, Gakhar L, Mathur SN, Sieren JC, Tyurina YY, Kagan VE, McLennan G, and Mallampalli RK (2010). Dynamic regulation of cardiolipin by the lipid pump Atp8b1 determines the severity of lung injury in experimental pneumonia. Nat Med 16(10): 1120-1127. doi: 10.1038/nm.2213
42. Carp H (1982). Mitochondrial $\mathrm{N}$-formylmethionyl proteins as chemoattractants for neutrophils. J Exp Med 155(1): 264-275. doi: 10.1084/jem.155.1.264

43. Le Y, Murphy PM, and Wang JM (2002). Formyl-peptide receptors revisited. Trends Immunol 23(11): 541-548. doi: 10.1016/s14714906(02)02316-5

44. Panaro MA, Acquafredda A, Sisto M, Lisi S, Maffione AB, and Mitolo $V$ (2006). Biological role of the $\mathrm{N}$-formyl peptide receptors. Immunopharmacol Immunotoxicol 28(1): 103-127. doi: 10.1080/08923970600625975

45. Czapiga M, Gao J-L, Kirk A, and Lekstrom-Himes J (2005). Human platelets exhibit chemotaxis using functional $\mathrm{N}$-formyl peptide receptors. Exp Hematol 33(1): 73-84. doi: 10.1016/j.exphem.2004.09.010

46. Rabiet M-J, Huet E, and Boulay F (2005). Human mitochondriaderived $\mathrm{N}$-formylated peptides are novel agonists equally active on FPR and FPRL1, while Listeria monocytogenes-derived peptides preferentially activate FPR. Eur J Immunol 35(8): 2486-2495. doi: 10.1002/eji.200526338

47. Daniel MA, McDonald G, Offenbacher S, and Van Dyke TE (1993). Defective chemotaxis and calcium response in localized juvenile periodontitis neutrophils. J Periodontol 64(7): 617-621. doi: 10.1902/jop.1993.64.7.617

48. Van Dyke TE, Levine MJ, Tabak LA, and Genco RJ (1981). Reduced chemotactic peptide binding in juvenile periodontitis: a model for neutrophil function. Biochem Biophys Res Commun 100(3): 12781284. doi: 10.1016/0006-291x(81)91962-8

49. Kozak M (1983). Comparison of initiation of protein synthesis in procaryotes, eucaryotes, and organelles. Microbiol Rev 47(1): 1-45. PMID: 6343825

50. Gustafsson CM, Falkenberg M, and Larsson N-G (2016). Maintenance and Expression of Mammalian Mitochondrial DNA. Annu Rev Biochem 85(1): annurev-biochem-060815-014402. doi: 10.1146/annurev-biochem-060815-014402

51. Kaufman B a, Newman SM, Hallberg RL, Slaughter C a, Perlman PS, and Butow R a (2000). In organello formaldehyde crosslinking of proteins to mtDNA: identification of bifunctional proteins. Proc Natl Acad Sci U S A 97(14): 7772-7. doi: 10.1073/pnas.140063197

52. Ngo HB, Lovely GA, Phillips R, and Chan DC (2014). Distinct structural features of TFAM drive mitochondrial DNA packaging versus transcriptional activation. Nat Commun 5: 3077 . doi: 10.1038/ncomms4077

53. Clayton DA (1982). Replication of animal mitochondrial DNA. Cell 28(4): 693-705. doi: 10.1016/0092-8674(82)90049-6

54. Bogenhagen DF (2012). Mitochondrial DNA nucleoid structure. Biochim Biophys Acta - Gene Regul Mech 1819(9-10): 914-920. doi: 10.1016/j.bbagrm.2011.11.005

55. Larsson NG, Wang J, Wilhelmsson $H$, Oldfors a, Rustin $P$, Lewandoski M, Barsh GS, and Clayton D a (1998). Mitochondrial transcription factor $A$ is necessary for mtDNA maintenance and embryogenesis in mice. Nat Genet 18: 231-236. doi: 10.1038/ng0398-231

56. Kukat C, Davies KM, Wurm C a., Spåhr H, Bonekamp N a., Kühl I, Joos F, Polosa PL, Park CB, Posse V, Falkenberg $M$, Jakobs $S$, Kühlbrandt W, and Larsson N-G (2015). Cross-strand binding of TFAM to a single mtDNA molecule forms the mitochondrial nucleoid. Proc Natl Acad Sci 112(36): 201512131. doi: 10.1073/pnas.1512131112

57. Brown TA, Tkachuk AN, Shtengel G, Kopek BG, Bogenhagen DF, Hess HF, and Clayton DA (2011). Superresolution Fluorescence Imaging of Mitochondrial Nucleoids Reveals Their Spatial Range, Limits, and Membrane Interaction. Mol Cell Biol 31(24): 4994-5010. doi: 10.1128/MCB.05694-11 
58. Kukat C, Wurm CA, Spåhr H, Falkenberg M, and Larsson N (2011). Super-resolution microscopy reveals that mammalian mitochondrial nucleoids have a uniform size and frequently contain a single copy of mtDNA. Proc Natl Acad Sci U S A 108(33):13534-9. doi: 10.1073/pnas.1109263108

59. Anderson S, Bankier AT, Barrell BG, de Bruijn MH, Coulson AR, Drouin J, Eperon IC, Nierlich DP, Roe BA, Sanger F, Schreier PH, Smith AJ, Staden R, and Young IG (1981). Sequence and organization of the human mitochondrial genome. Nature 290(5806): 457-465. doi: 10.1038/290457a0

60. Clayton DA, Hughes $H$, and Chase $C$ (2000). Transcription and replication of mitochondrial DNA. Hum Reprod 15(Suppl 2): 11-17. doi: 10.1093/humrep/15.suppl_2.11

61. Oka T, Hikoso S, Yamaguchi O, Taneike M, Takeda T, Tamai T, Oyabu J, Murakawa T, Nakayama H, Nishida K, Akira S, Yamamoto A, Komuro I, and Otsu K (2012). Mitochondrial DNA that escapes from autophagy causes inflammation and heart failure. Nature 485(7397): 251-5. doi: 10.1038/nature10992

62. McCarthy CG, Wenceslau CF, Goulopoulou S, Ogbi S, Baban B, Sullivan JC, Matsumoto T, and Webb RC (2015). Circulating mitochondrial DNA and Toll-like receptor 9 are associated with vascular dysfunction in spontaneously hypertensive rats. Cardiovasc Res 107(1): 119-130. doi: 10.1093/cvr/cvv137

63. Nakahira K, Haspel JA, Rathinam V a K, Lee S-J, Dolinay T, Lam HC, Englert J a, Rabinovitch $M$, Cernadas $M$, Kim HP, Fitzgerald $\mathrm{K}$ a, Ryter SW, and Choi AMK (2011). Autophagy proteins regulate innate immune responses by inhibiting the release of mitochondrial DNA mediated by the NALP3 inflammasome. Nat Immunol 12(3): 222-30. doi: 10.1038/ni.1980

64. West AP, Khoury-Hanold W, Staron M, Tal MC, Pineda CM, Lang SM, Bestwick M, Duguay BA, Raimundo N, MacDuff DA, Kaech SM, Smiley JR, Means RE, Iwasaki A, and Shadel GS (2015). Mitochondrial DNA stress primes the antiviral innate immune response. Nature 520(7548): 553-557. doi: 10.1038/nature14156

65. Picca A, LEZZA AMS, Leeuwenburgh C, PESCE V, Calvani R, Bossola M, Manes-Gravina E, Landi F, Bernabei R, and Marzetti E (2017). Circulating mitochondrial DNA at the crossroads of mitochondrial dysfunction and inflammation during aging and muscle wasting disorders. Rejuvenation Res 39(06): rej.2017.1989. doi: 10.1089/rej.2017.1989

66. Hong EE, Okitsu CY, Smith AD, and Hsieh C-L (2013). Regionally Specific and Genome-Wide Analyses Conclusively Demonstrate the Absence of CpG Methylation in Human Mitochondrial DNA. Mol Cell Biol 33(14): 2683-2690. doi: 10.1128/MCB.00220-13

67. Shock LS, Thakkar P V., Peterson EJ, Moran RG, and Taylor SM (2011). DNA methyltransferase 1, cytosine methylation, and cytosine hydroxymethylation in mammalian mitochondria. Proc Natl Acad Sci 108(9): 3630-3635. doi: 10.1073/pnas.1012311108

68. Shimada K, Crother TR, Karlin J, Dagvadorj J, Chiba N, Chen S, Ramanujan VK, Wolf AJ, Vergnes L, Ojcius DM, Rentsendorj A, Vargas M, Guerrero $C$, Wang $Y$, Fitzgerald $K$ a, Underhill DM, Town $T$, and Arditi $M$ (2012). Oxidized mitochondrial DNA activates the NLRP3 inflammasome during apoptosis. Immunity 36(3): 401-14. doi: 10.1016/j.immuni.2012.01.009

69. Collins LV, Hajizadeh S, Holme E, Jonsson I, and Tarkowski A (2004) Endogenously oxidized mitochondrial DNA induces in vivo and in vitro inflammatory responses. J Leukoc Biol 75(June): 995-1000. doi: 10.1189/jlb.0703328.1

70. Tsuji N, Tsuji T, Ohashi N, Kato A, Fujigaki Y, and Yasuda H (2015). Role of Mitochondrial DNA in Septic AKI via Toll-Like Receptor 9. J Am Soc Nephrol 27(7):2009-20. doi: 10.1681/ASN.2015040376

71. Marques PE, Amaral SS, Pires DA, Nogueira LL, Soriani FM, Lima
BHF, Lopes GAO, Russo RC, Avila T V, Melgaco JG, Oliveira AG, Pinto MA, Lima CX, De Paula AM, Cara DC, Leite MF, Teixeira MM, and Menezes GB (2012). Chemokines and mitochondrial products activate neutrophils to amplify organ injury during mouse acute liver failure. Hepatology 56(5): 1971-1982. doi: 10.1002/hep.25801

72. Zhang L, Deng S, Zhao S, Ai Y, Zhang L, Pan P, Su X, Tan H, and Wu $D$ (2016). Intra-Peritoneal Administration of Mitochondrial DNA Provokes Acute Lung Injury and Systemic Inflammation via Toll-Like Receptor 9. Int J Mol Sci 17(9): 1425. doi: 10.3390/ijms17091425

73. Zhang Q, Itagaki K, and Hauser CJ (2010). Mitochondrial DNA is released by shock and activates neutrophils via $\mathrm{p} 38$ map kinase. Shock 34(1): 55-9. doi: 10.1097/SHK.0b013e3181cd8c08

74. Wilkins HM, Koppel SJ, Weidling IW, Roy N, Ryan LN, Stanford JA, and Swerdlow RH (2016). Extracellular Mitochondria and Mitochondrial Components Act as Damage-Associated Molecular Pattern Molecules in the Mouse Brain. J Neuroimmune Pharmacol 11(4):622-628. doi: 10.1007/s11481-016-9704-7

75. Wilkins HM, Carl SM, Weber SG, Ramanujan SA, Festoff BW, Linseman DA, and Swerdlow RH (2015). Mitochondrial Lysates Induce Inflammation and Alzheimer's Disease-Relevant Changes in Microglial and Neuronal Cells. J Alzheimers Dis 45(1): 305-318. doi: 10.3233/JAD-142334. Mitochondrial

76. Campbell CT, Kolesar JE, and Kaufman BA (2012). Mitochondrial transcription factor $A$ regulates mitochondrial transcription initiation, DNA packaging, and genome copy number. Biochim Biophys Acta 1819(9-10): 921-929. doi: 10.1016/j.bbagrm.2012.03.002

77. Kang D, Kim SH, and Hamasaki N (2007). Mitochondrial transcription factor A (TFAM): roles in maintenance of mtDNA and cellular functions. Mitochondrion 7(1-2): 39-44. doi: 10.1016/j.mito.2006.11.017

78. Julian MW, Shao G, Bao S, Knoell DL, Papenfuss TL, VanGundy ZC, and Crouser ED (2012). Mitochondrial transcription factor A serves as a danger signal by augmenting plasmacytoid dendritic cell responses to DNA. J Immunol 189(1): 433-43. doi: 10.4049/jimmunol.1101375

79. Julian MW, Shao G, Vangundy ZC, Papenfuss TL, and Crouser ED (2013). Mitochondrial transcription factor $A$, an endogenous danger signal, promotes TNF $\alpha$ release via RAGE- and TLR9-responsive plasmacytoid dendritic cells. PLoS One 8(8): e72354. doi: 10.1371/journal.pone.0072354

80. Crouser ED, Shao G, Julian MW, Macre JE, Shadel GS, Tridandapani, Susheela Huang $Q$, and D. Wewers M (2010). Monocyte Activation by Necrotic Cells Is Promoted by Mitochondrial Proteins and Formyl Peptide Receptors Elliott. Crit Care Med 37(6): 2000-2009. doi: 10.1097/CCM.0b013e3181a001ae.Monocyte

81. Chaung WW, Wu R, Ji Y, Dong W, and Wang P (2012). Mitochondrial transcription factor $A$ is a proinflammatory mediator in hemorrhagic shock. Int J Mol Med 30(1): 199-203. doi: 10.3892/ijmm.2012.959

82. Zhang $Q$, Raoof $M$, Chen $Y$, Sumi $Y$, Sursal $T$, Junger $W$, Brohi $K$, Itagaki K, and Hauser CJ (2010). Circulating mitochondrial DAMPs cause inflammatory responses to injury. Nature 464(7285): 104-107. doi: $10.1038 /$ nature 08780

83. Hu Q, Wood CR, Cimen S, Venkatachalam AB, and Alwayn IPJ (2015). Mitochondrial damage-associated molecular patterns (MTDs) are released during hepatic ischemia reperfusion and induce inflammatory responses. PLoS One 10(10): 1-17. doi: 10.1371/journal.pone.0140105

84. Schoenauer R, Atanassoff AP, Wolfmeier H, Pelegrin P, Babiychuk $E B$, and Draeger A (2014). P2X7 receptors mediate resistance to toxininduced cell lysis. Biochim Biophys Acta - Mol Cell Res 1843(5): 915922. doi: 10.1016/j.bbamcr.2014.01.024 
85. Duregotti E, Negro S, Scorzeto M, Zornetta I, Dickinson BC, Chang CJ, Montecucco C, and Rigoni M (2015). Mitochondrial alarmins released by degenerating motor axon terminals activate perisynaptic Schwann cells. Proc Natl Acad Sci 112(5): E497-E505. doi: 10.1073/pnas.1417108112

86. Liu J, Epand RF, Durrant D, Grossman D, Chi N, Epand RM, and Lee RM (2008). Role of phospholipid scramblase 3 in the regulation of tumor necrosis factor-alpha-induced apoptosis. Biochemistry 47(15): 4518-4529. doi: 10.1021/bi701962c

87. Chu CT, Ji J, Dagda RK, Jiang JF, Tyurina YY, Kapralov AA, Tyurin VA, Yanamala N, Shrivastava IH, Mohammadyani D, Wang KZQ, Zhu J, Klein-Seetharaman J, Balasubramanian K, Amoscato AA, Borisenko G, Huang Z, Gusdon AM, Cheikhi A, Steer EK, Wang R, Baty C, Watkins S, Bahar I, Bayir H, and Kagan VE (2013). Cardiolipin externalization to the outer mitochondrial membrane acts as an elimination signal for mitophagy in neuronal cells. Nat Cell Biol 15(10): 1197-1205. doi: $10.1038 /$ ncb2837

88. Iyer SS, He Q, Janczy JR, Elliott El, Zhong Z, Olivier AK, Sadler JJ, Knepper-Adrian V, Han R, Qiao L, Eisenbarth SC, Nauseef WM, Cassel $\mathrm{SL}$, and Sutterwala FS (2013). Mitochondrial cardiolipin is required for NIrp3 inflammasome activation. Immunity 39(2): 311-23. doi: 10.1016/j.immuni.2013.08.001

89. Sun S, Sursal T, Adibnia Y, Zhao C, Zheng Y, Li H, Otterbein LE, Hauser CJ, and Itagaki K (2013). Mitochondrial DAMPs increase endothelial permeability through neutrophil dependent and independent pathways. PLoS One 8(3): e59989. doi: 10.1371/journal.pone.0059989

90. He W, Miao FJ-P, Lin DC-H, Schwandner RT, Wang Z, Gao J, Chen J$L$, Tian $H$, and Ling $L$ (2004). Citric acid cycle intermediates as ligands for orphan G-protein-coupled receptors. Nature 429(6988): 188-193. doi: $10.1038 /$ nature 02488

91. Migeotte I, Communi D, and Parmentier M (2006). Formyl peptide receptors: a promiscuous subfamily of $\mathrm{G}$ protein-coupled receptors controlling immune responses. Cytokine Growth Factor Rev 17(6): 501-519. doi: 10.1016/j.cytogfr.2006.09.009

92. West AP, and Shadel GS (2017). Mitochondrial DNA in innate immune responses and inflammatory pathology. Nat Rev Immunol 17(6): 363-375. doi: 10.1038/nri.2017.21

93. Takeuchi $O$, and Akira S (2010). Pattern recognition receptors and inflammation. Cell 140(6): 805-20. doi: 10.1016/j.cell.2010.01.022

94. Wu J, Sun L, Chen X, Du F, Shi H, Chen C, and Chen ZJ (2013). Cyclic GMP-AMP is an endogenous second messenger in innate immune signaling by cytosolic DNA. Science 339(6121): 826-830. doi: 10.1126/science. 1229963

95. Sun L, Wu J, Du F, Chen X, and Chen ZJ (2012). Cyclic GMP-AMP Synthase Is a Cytosolic DNA Sensor That Activates the Type I Interferon Pathway. Science 339(6121): 1-10. doi: 10.1126/science.1232458

96. Cai D (2009). NFkappaB-mediated metabolic inflammation in peripheral tissues versus central nervous system. Cell Cycle 8(16): 25428. doi: $10.4161 /$ cc.8.16.9386

97. Ishii KJ, Coban C, Kato H, Takahashi K, Torii Y, Takeshita F, Ludwig H, Sutter G, Suzuki K, Hemmi H, Sato S, Yamamoto M, Uematsu S, Kawai T, Takeuchi O, and Akira S (2006). A Toll-like receptorindependent antiviral response induced by double-stranded B-form DNA. Nat Immunol 7(1): 40-48. doi: 10.1038/ni1282

98. Ishikawa $\mathrm{H}$, and Barber GN (2008). STING is an endoplasmic reticulum adaptor that facilitates innate immune signalling. Nature 455(7213): 674-678. doi: 10.1038/nature07317

99. Stetson DB, and Medzhitov R (2006). Recognition of cytosolic DNA activates an IRF3-dependent innate immune response. Immunity 24(1): 93-103. doi: 10.1016/j.immuni.2005.12.003
100. Ishikawa H, Ma Z, and Barber GN (2009). STING regulates intracellular DNA-mediated, type I interferon-dependent innate immunity. Nature 461(7265): 788-792. doi: 10.1038/nature08476

101. Zhong B, Yang Y, Li S, Wang Y-Y, Li Y, Diao F, Lei C, He X, Zhang L, Tien $P$, and Shu H-B (2008). The adaptor protein MITA links virussensing receptors to IRF3 transcription factor activation. Immunity 29(4): 538-550. doi: 10.1016/j.immuni.2008.09.003

102. Lei Z, Deng M, Yi Z, Sun Q, Shapiro RA, Xu H, Li T, Loughran PA, Griepentrog JE, Huang H, Scott MJ, Huang F, and Billiar TR (2018). cGAS-mediated autophagy protects the liver from ischemia/reperfusion injury independent of STING. Am J Physiol Liver Physiol (5): ajpgi.00326.2017. doi: 10.1152/ajpgi.00326.2017

103. Andreeva L, Hiller B, Kostrewa D, Lässig C, de Oliveira Mann CC, Jan Drexler D, Maiser A, Gaidt M, Leonhardt H, Hornung V, and Hopfner K-P (2017). cGAS senses long and HMGB/TFAM-bound U-turn DNA by forming protein-DNA ladders. Nature 549(7672): 394-398. doi: $10.1038 /$ nature23890

104. Bai J, Cervantes C, Liu J, He S, Zhou H, Zhang B, Cai H, Yin D, Hu D, Li Z, Chen H, Gao X, Wang F, O'Connor JC, Xu Y, Liu M, Dong LQ, and Liu $F$ (2017). DsbA-L prevents obesity-induced inflammation and insulin resistance by suppressing the mtDNA release-activated cGAScGAMP-STING pathway. Proc Natl Acad Sci 114(46): 201708744. doi: 10.1073/pnas.1708744114

105. McArthur K, Whitehead LW, Heddleston JM, Li L, Padman BS, Oorschot V, Geoghegan ND, Chappaz S, Davidson S, Chin HS, Lane RM, Dramicanin M, Saunders TL, Sugiana C, Lessene R, Osellame LD, Chew TL, Dewson G, Lazarou M, Ramm G, Lessene G, Ryan MT, Rogers KL, Van Delft MF, and Kile BT (2018). BAK/BAX macropores facilitate mitochondrial herniation and mtDNA efflux during apoptosis. Science 359(6378). doi: 10.1126/science.aao6047

106. Kim G-T, Cho M-L, Park Y-E, Yoo WH, Kim J-H, Oh H-J, Kim D-S, Baek S-H, Lee S-H, Lee J-H, Kim H-Y, and Kim S-I (2010). Expression of TLR2, TLR4, and TLR9 in dermatomyositis and polymyositis. Clin Rheumatol 29(3): 273-279. doi: 10.1007/s10067-009-1316-7

107. Barbalat R, Ewald SE, Mouchess ML, and Barton GM (2011). Nucleic acid recognition by the innate immune system. Annu Rev Immunol 29: 185-214. doi: 10.1146/annurev-immunol-031210-101340

108. Latz E, Schoenemeyer A, Visintin A, Fitzgerald KA, Monks BG, Knetter CF, Lien E, Nilsen NJ, Espevik T, and Golenbock DT (2004). TLR9 signals after translocating from the ER to CPG DNA in the lysosome. Nat Immunol 5(2): 190-8. doi: 10.1038/ni1028

109. Lamphier MS, Sirois CM, Verma A, Golenbock DT, and Latz E (2006). TLR9 and the recognition of self and non-self nucleic acids. Ann N Y Acad Sci 1082: 31-43. doi: 10.1196/annals.1348.005

110. Leifer CA, Kennedy MN, Mazzoni A, Lee C, Kruhlak MJ, and Sega DM (2004). TLR9 is localized in the endoplasmic reticulum prior to stimulation. J Immunol 173(2): 1179-1183. doi: 10.4049/jimmunol.173.2.1179

111. Ewald SE, Lee BL, Lau L, Wickliffe KE, Shi GP, Chapman HA, and Barton GM (2008). The ectodomain of Toll-like receptor 9 is cleaved to generate a functional receptor. Nature 456(7222): 658-662. doi: $10.1038 /$ nature07405

112. Chockalingam A, Brooks JC, Cameron JL, Blum LK, and Leifer CA (2009). TLR9 traffics through the Golgi complex to localize to endolysosomes and respond to CpG DNA. Immunol Cell Biol 87(3): 209-217. doi: 10.1038/icb.2008.101

113. Tabeta K, Hoebe K, Janssen EM, Du X, Georgel P, Crozat K, Mudd S, Mann N, Sovath S, Goode J, Shamel L, Herskovits AA, Portnoy DA, Cooke M, Tarantino LM, Wiltshire T, Steinberg BE, Grinstein S, and Beutler B (2006). The Unc93b1 mutation 3d disrupts exogenous antigen presentation and signaling via Toll-like receptors 3, 7 and 9. Nat 


\section{Immunol 7(2): 156-164. doi: 10.1038/ni1297.}

114. Fukui R, Saitoh S, Matsumoto F, Kozuka-Hata H, Oyama M, Tabeta K, Beutler B, and Miyake K (2009). Unc93B1 biases Toll-like receptor responses to nucleic acid in dendritic cells toward DNA- but against RNA-sensing. J Exp Med. 206(6): 1339-1350. doi: 10.1084/jem.20082316.

115. Pelka K, Phulphagar K, Zimmermann J, Stahl R, Schmid-Burgk JL, Schmidt T, Spille J-H, Labzin LI, Agrawal S, Kandimalla ER, Casanova J-L, Hornung V, Marshak-Rothstein A, Höning S, and Latz E (2014). Cutting edge: the UNC93B1 tyrosine-based motif regulates trafficking and TLR responses via separate mechanisms. J Immunol 193(7): 3257-61. doi: 10.4049/jimmunol.1301886

116. Hayashi K, Sasai M, and Iwasaki A (2015). Toll-like receptor 9 trafficking and signaling for type i interferons requires PIKfyve activity. Int Immunol 27(9): 435-445. doi: 10.1093/intimm/dxv021

117. Honda K, Ohba Y, Yanai H, Negishi H, Mizutani T, Takaoka A, Taya $C$, and Taniguchi T (2005). Spatiotemporal regulation of MyD88-IRF-7 signalling for robust type-I interferon induction. Nature 434(7036): 1035-1040. doi: 10.1038/nature03547

118. Lee BL, and Barton GM (2014). Trafficking of endosomal Toll-like receptors. Trends Cell Biol 24(6): 360-369. doi: 10.1016/j.tcb.2013.12.002

119. Duhamel M, Rodet F, Murgoci AN, Desjardins R, Gagnon H, Wisztorski M, Fournier I, Day R, and Salzet M (2016). The proprotein convertase $\mathrm{PC1} / 3$ regulates TLR9 trafficking and the associated signaling pathways. Sci Rep 6: 19360. doi: 10.1038/srep19360

120. Shintani Y, Kapoor A, Kaneko M, Smolenski RT, D'Acquisto F, Coppen SR, Harada-Shoji N, Lee HJ, Thiemermann C, Takashima S, Yashiro K, and Suzuki K (2013). TLR9 mediates cellular protection by modulating energy metabolism in cardiomyocytes and neurons. Proc Natl Acad Sci U S A 110(13): 5109-14. doi: 10.1073/pnas.1219243110

121. Shintani $Y$, Drexler HC, Kioka H, Terracciano CM, Coppen SR, Imamura H, Akao M, Nakai J, Wheeler AP, Higo S, Nakayama H, Takashima S, Yashiro K, and Suzuki K (2014). Toll-like receptor 9 protects non-immune cells from stress by modulating mitochondrial ATP synthesis through the inhibition of SERCA2. EMBO Rep 15(4): 438-445. doi: 10.1002/embr.201337945

122. Hajizadeh S, DeGroot J, TeKoppele JM, Tarkowski A, and Collins LV (2003). Extracellular mitochondrial DNA and oxidatively damaged DNA in synovial fluid of patients with rheumatoid arthritis. Arthritis Res Ther 5(5): R234-40. doi: 10.1186/ar787

123. Ding Z, Liu S, Wang X, Khaidakov M, Dai Y, and Mehta JL (2013). Oxidant stress in mitochondrial DNA damage, autophagy and inflammation in atherosclerosis. Sci Rep 3: 1077. doi: 10.1038/srep01077

124. Yao X, Carlson D, Sun Y, Ma L, Wolf SE, Minei JP, and Zang QS (2015). Mitochondrial ROS Induces Cardiac Inflammation via a Pathway through mtDNA Damage in a Pneumonia-Related Sepsis Model. PLoS One 10(10): e0139416. doi: 10.1371/journal.pone.0139416

125. Zhang L, Deng S, Zhao S, Ai Y, Zhang L, Pan P, Su X, Tan H, and Wu $D$ (2016). Intra-peritoneal administration of mitochondrial DNA provokes acute lung injury and systemic inflammation via toll-like receptor 9. Int J Mol Sci 17(9): 1-16. doi: 10.3390/ijms17091425

126. Li Y, Berke IC, and Modis Y (2012). DNA binding to proteolytically activated TLR9 is sequence-independent and enhanced by DNA curvature. EMBO J 31(4): 919-31. doi: 10.1038/emboj.2011.441

127. Zhang JZ, Liu Z, Liu J, Ren JX, and Sun TS (2014). Mitochondrial DNA induces inflammation and increases TLR9/NF-KB expression in lung tissue. Int J Mol Med 33(4): 817-824. doi: 10.3892/ijmm.2014.1650

128. Bao W, Xia H, Liang Y, Ye Y, Lu Y, Xu X, Duan A, He J, Chen Z, Wu Y,
Wang X, Zheng C, Liu Z, and Shi S (2016). Toll-like Receptor 9 Can be Activated by Endogenous Mitochondrial DNA to Induce Podocyte Apoptosis. Sci Rep 6: 22579. doi: 10.1038/srep22579

129. Garcia-martinez I, Santoro N, Chen Y, Hoque R, Ouyang X, Caprio S, Shlomchik MJ, Coffman RL, Candia A, and Mehal WZ (2016). Hepatocyte mitochondrial DNA drives nonalcoholic steatohepatitis by activation of TLR9. J Clin Invest 126(3): 1-6. doi: 10.1172/JCl83885DS1

130. Kuck JL, Obiako BO, Gorodnya OM, Pastukh VM, Kua J, Simmons JD, and Gillespie MN (2015). Mitochondrial DNA damage-associated molecular patterns mediate a feed-forward cycle of bacteria-induced vascular injury in perfused rat lungs. Am J Physiol - Lung Cell Mol Physiol 308(10): L1078-L1085. doi: 10.1152/ajplung.00015.2015

131. Goulopoulou S, Matsumoto T, Bomfim GF, and Webb RC (2012) Toll-like receptor 9 activation: a novel mechanism linking placentaderived mitochondrial DNA and vascular dysfunction in pre-eclampsia. Clin Sci 123(7): 429-35. doi: 10.1042/CS20120130

132. Tian J, Avalos AM, Mao S-Y, Chen B, Senthil K, Wu H, Parroche $P$, Drabic S, Golenbock D, Sirois C, Hua J, An LL, Audoly L, La Rosa G, Bierhaus A, Naworth P, Marshak-Rothstein A, Crow MK, Fitzgerald K a, Latz E, Kiener $\mathrm{P}$ a, and Coyle AJ (2007). Toll-like receptor 9-dependent activation by DNA-containing immune complexes is mediated by HMGB1 and RAGE. Nat Immunol 8(5): 487-96. doi: 10.1038/ni1457

133. Julian MW, Shao G, Bao S, Knoell DL, Papenfuss TL, Vangundy ZC, Crouser ED, Daren L, Papenfuss TL, Vangundy ZC, and Crouser ED (2012). Mitochondrial transcription factor $A$ serves as a danger signal by augmenting plasmacytoid dendritic cell responses to DNA. J Immunol 189(1): 433-443. doi: 10.4049/jimmunol.1101375

134. Leo MG De, Staiano L, Vicinanza M, Luciani A, Carissimo A, Mutarelli M, Campli A Di, Polishchuk E, Tullio G Di, Morra V, Levtchenko $E$, Oltrabella $F$, Starborg $T$, Santoro $M$, Bernardo $D$, Devuyst O, Lowe M, Medina DL, Ballabio A, and Matteis MA De (2016). Autophagosome - lysosome fusion triggers a lysosomal response mediated by TLR9 and controlled by OCRL. Nat Cell Biol 18(8): 839850. doi: $10.1038 /$ ncb3386

135. Rodríguez-Nuevo A, Díaz-Ramos A, Noguera E, Díaz-Sáez F, Duran $X$, Muñoz JP, Romero M, Plana N, Sebastián D, Tezze C, Romanello V, Ribas F, Seco J, Planet E, Doctrow SR, González J, Borràs M, Liesa M, Palacín M, Vendrell J, Villarroya F, Sandri M, Shirihai O, and Zorzano A (2018). Mitochondrial DNA and TLR9 drive muscle inflammation upon Opa1 deficiency. EMBO J 37(10): e96553. doi: 10.15252/embj.201796553

136. Liu Y, Yan W, Tohme S, Chen M, Fu Y, Tian D, Lotze M, Tang D, and Tsung $A$ (2015). Hypoxia induced HMGB1 and mitochondrial DNA interactions mediate tumor growth in hepatocellular carcinoma through Toll Like Receptor 9. J Hepatol 63(1): 114-121. doi: 10.1016/j.jhep.2015.02.009

137. Green NM, and Marshak-Rothstein A (2011). Toll-like receptor driven $B$ cell activation in the induction of systemic autoimmunity. Semin Immunol 23(2): 106-112. doi: 10.1016/j.smim.2011.01.016

138. Santiago-Raber ML, Baudino L, and Izui S (2009). Emerging roles of TLR7 and TLR9 in murine SLE. J Autoimmun 33(3-4): 231-238. doi 10.1016/j.jaut.2009.10.001

139. Lamphier $M$, Zheng $W$, Latz $E$, Spyvee $M$, Hansen $H$, Rose J, Genest $M$, Yang $H$, Shaffer $C$, Zhao $Y$, Shen $Y$, Liu C, Liu D, Mempel TR, Rowbottom C, Chow J, Twine NC, Yu M, Gusovsky F, and Ishizaka ST (2014). Novel small molecule inhibitors of TLR7 and TLR9: mechanism of action and efficacy in vivo. Mol Pharmacol 85(3): 429-40. doi: 10.1124/mol.113.089821

140. Broz P, and Dixit VM (2016). Inflammasomes: mechanism of assembly, regulation and signalling. Nat Rev Immunol 16(7): 407-420. doi: 10.1038/nri.2016.58 
141. Man SM, and Kanneganti T-D (2015). Converging roles of caspases in inflammasome activation, cell death and innate immunity. Nat Rev Immunol 16(1): 7-21. doi: 10.1038/nri.2015.7

142. Place DE, and Kanneganti TD (2018). Recent advances in inflammasome biology. Curr Opin Immunol 50: 32-38. doi: 10.1016/j.coi.2017.10.011

143. Kawaguchi $M$, Takahashi $M$, Hata $T$, Kashima $Y$, Usui $F$, Morimoto H, Izawa A, Takahashi Y, Masumoto J, Koyama J, Hongo M, Noda T, Nakayama J, Sagara J, Taniguchi S, and Ikeda U (2011). Inflammasome activation of cardiac fibroblasts is essential for myocardial ischemia/reperfusion injury. Circulation 123(6): 594-604. doi: 10.1161/CIRCULATIONAHA.110.982777

144. Wree A, Eguchi A, McGeough MD, Pena C a, Johnson CD, Canbay A, Hoffman HM, and Feldstein AE (2013). NLRP3 inflammasome activation results in hepatocyte pyroptosis, liver inflammation and fibrosis. Hepatology 1: 1-33. doi: 10.1002/hep.26592

145. Boaru SG, Borkham-Kamphorst E, Van de Leur E, Lehnen E, Liedtke C, and Weiskirchen R (2015). NLRP3 inflammasome expression is driven by NF-KB in cultured hepatocytes. Biochem Biophys Res
Commun 458(3): 700-706. doi: 10.1016/j.bbrc.2015.02.029

146. Kanneganti TD (2015). The inflammasome: Firing up innate immunity. Immunol Rev 265(1): 1-5. doi: 10.1111/imr.12297

147. Shahzad K, Bock F, Dong W, Wang H, Kopf S, Kohli S, Al-Dabet MM, Ranjan S, Wolter J, Wacker C, Biemann R, Stoyanov S, Reymann K, Söderkvist P, Groß O, Schwenger V, Pahernik S, Nawroth PP, Gröne H-J, Madhusudhan T, and Isermann B (2014). Nlrp3-inflammasome activation in non-myeloid-derived cells aggravates diabetic nephropathy. Kidney Int 87(1): 74-84. doi: 10.1038/ki.2014.271

148. Zhuang Y, Yasinta M, Hu C, Zhao M, Ding G, Bai M, Yang L, Ni J, Wang R, Jia Z, Huang S, and Zhang A (2015). Mitochondrial dysfunction confers albumin-induced NLRP3 inflammasome activation and renal tubular injury. Am J Physiol - Ren Physiol 308(8): F857-F866. doi: 10.1152/ajprenal.00203.2014

149. Rawat R, Cohen T V, Ampong B, Francia D, Henriques-Pons A, Hoffman EP, and Nagaraju K (2010). Inflammasome up-regulation and activation in dysferlin-deficient skeletal muscle. Am J Pathol 176(6) 2891-900. doi: 10.2353/ajpath.2010.090058 